\title{
THE INTERNATIONAL CONGRESS OF AFRICAN STUDIES
}

[The following letter was sent to Professor John H. Clarke (Department of Black and Puerto Rican Studies, Hunter College), U.S. Delegate the the International Congress of African Studies.]

April 10, 1977

Dear Professor and Colleague:

I was happy to receive your letter of 7 December and I thank you sincerely for it.

The Executive Committee of the Congress which met in Kinshasa the 10th and 11th of December 1976 regretted your absence very much. I hope that the kind of lateness that occured will not happen again so that you might be able to take part in all of the meetings of the CIAF.

The next newsletter which will be sent out shortly will give you the highlights of the issues which were on the agenda.

Nonetheless, following is a schedule for future meetings:

In 1977, at Khartoum (Sudan)

1. 18 December, Meeting of the Executive Committee of the Congress.

2. 19-21 December, Colloquium on the theme: "Review of the Phenomenon of and Lessons to be learned from the Drought of the 70s."

In 1978

1. 28 May, Meeting of the Executive Committee of the Congress, Rabat, Morocco.

2. 19-31 May, Colloquium on "The Problems of Technologies in Africa," Rabat, Morocco.

3. 11 December, Meeting of the Executive Committee of the Congress in Kinshasa.

4. 12-16 December, Fourth Session of the Congress in Kinshasa.

For more information I am sending you under separate cover the CIAF Newsletters No. 1, 2, 3, and very soon No. 4.

In the hope that we will soon count on your collaboration and effective participation, I extend my sincerest sentiments.

For the Secretary General NSEYA Kahangu Assistant to the Office of CIAF

\section{LETTER}

The African Studies Association

The New York Public Library Astor, Lenox and Tilden Foundations

The Research Libraries

Fifth Avenue \& 42nd Street

New York, N.Y. 10018

218 Shiffman Center

Brandeis University

Wal tham, Mass. 02154

April 18, 1977

Gentlepersons:

In your February 1977 issue you published a statement relative to the Schomburg Center for Research in Black Culture. That statement contains errors of fact which I suggest you may wish to correct. 
The New York Public Library failed to give "regular" appointments to two members of the Schomburg staff after they had completed two years in a probationary status: The right of the Library to withhold regular appointment is included in the contract between the Library and the Union which represents the affected staff members.

The new building for Schomburg was requested of the City of New York by the New York Public Library and the City requested funds for the new building from the federal government under the Public Works Employment Act of 1976. The amount requested by the City was $\$ 3.7$ million. The original request to the City had been for two additional parts of a total cultural complex: a new building for the Countee Cullen Branch Library and a museum of art and artifacts representative of black culture. The City did not agree to finance the construction of these two units. The original plan submitted to the City called for a Schomburg Library of 40,000 square feet. The building now under construction will consist of 40,000 square feet.

Contrary to what has been said in the statement referred to above, the New York Public Library has at no time spent any of its funds on construction or renovation of the Lincoln Center Library \& Museum of the Performing Arts. The building is City-owned, having been paid for by the City of New York.

A broken boiler and problems connected with its replacement made it necessary to close the present Schomburg Center building for a number of days during the difficult winter just past. There was no other reason for the closing of the Library.

The New York Public Library and the Schomburg Corporation, a group of individuals interested in Schomburg's welfare, working together, have secured, since 1972 , three grants totalling $\$ 1,259,810$ from the National Endowment for the Humanities. These grants have been used exclusively for the benefit of Schomburg and can be used in no other way.

Sincerely yours, James $W$. Henderson Andrew W. Mellon Director of The Research Libraries

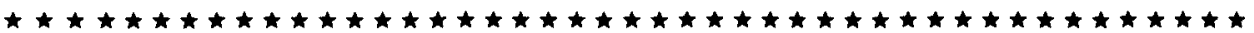

\title{
BLACK AFRICA DEVELOPS
}

\author{
William A. Hance \\ Volume 1 in the A.S.A. Basic Africana Library
}

Black Africa Develops is a brief, authoritative introduction to the developing economies of tropical Africa. Designed to provide a fundamental understanding of this fascinating and diverse area and its problems, it is suitable both as a textbook and as a sourcebook for a wealth of up-to-date information on sub-Saharan Africa.

The book examines such questions as: What are the impacts of rapid population growth? Why have so many argicultural schemes failed? How can farming be more effectively advanced? What roles should mining and manufacturing play? Does the "new economic order" hold promise for Africa? Why are some countries making much more satisfactory progress than others?

William Hance is Professor of Economic Geography and a member of the Institute of African Studies at Columbia University. Frequent trips to Africa over the past thirty years have contributed to the realism that characterizes Dr. Hance's writings, which include African Economic Development, Population, Migration, and Urbanization in Africa, The Geography of Modern Africa, and many journal articles. He is a founding fellow and past-president of the African Studies Association and an honorary fellow of the American Geographic Society.

176 pages

maps and illustrations

$\$ 8.00$-clothbound

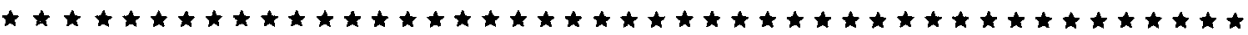

